\title{
Similar bronchodilation with formoterol delivered by Aerolizer or Turbuhaler
}

\author{
J Lötvall MD PhD ${ }^{1}, A$ Mellén $M D^{1}, P$ Arvidsson $M D^{1}$, \\ $M$ Palmqvist MD PhD ${ }^{1}, P$ Radielovic $M D^{2}$, J Kottakis $M D^{3}, P$ Pfister $M D^{2}$ \\ ${ }^{1}$ Department of Respiratory Medicine and Allergology, Institute of Heart and Lung Diseases, \\ Göteborg University, Sahlgrenska University Hospital, \\ Gothenburg, Sweden; ${ }^{2}$ Clinical Development \& Regulatory Affairs, Novartis Pharma, Basel, \\ Switzerland; ${ }^{3}$ Medical School, University of Crete, Greece
}

\begin{abstract}
J Lötvall, A Mellén, P Arvidsson, et al. Similar bronchodilation with formoterol delivered by Aerolizer or Turbuhaler. Can Respir J 1999;6(5):412-416.
\end{abstract}

BACKGROUND: In many countries, two dry powder formulations of inhaled formoterol are available for clinical use; one uses a single-dose device (Foradil, Aerolizer), and the other uses a multiple-dose device (Oxis, Turbuhaler).

OBJECTIVES: To study the bronchodilating effect of formoterol $12 \mu \mathrm{g}$ when delivered via the Aerolizer and Turbuhaler devices over $12 \mathrm{~h}$.

STUDY DESIGN: Randomized, double-blind, placebo controlled crossover study. Forced expiratory volume in one second $\left(\mathrm{FEV}_{1}\right)$ was monitored during a $12 \mathrm{~h}$ period.

PATIENTS: Nineteen nonsmoking asthma patients were included in the trial on the basis of reversibility of symptoms in response to inhaled salbutamol (either 200 or $400 \mu \mathrm{g}$ given cumulatively; minimum reversibility $15 \%$ ).

RESULTS: There were no significant differences between the two dry powder devices regarding the change from baseline of FEV 1 over $12 \mathrm{~h}$, the area under the curve of $\mathrm{FEV}_{1}$ over $12 \mathrm{~h}$ or the maximum value of $\mathrm{FEV}_{1}$. The improvement in $\mathrm{FEV}_{1}$ with formoterol $12 \mu \mathrm{g}$ versus placebo was highly significant for both devices.

CONCLUSIONS: Formoterol is similarly effective when used as a dry powder when given by either Aerolizer or the Turbuhaler.

Key Words: Asthma; Beta 2 -agonist; Bronchodilators; Inhalation therapy

\section{Bronchodilatation similaire avec du formotérol délivré par Aerolizer ou Turbuhaler}

HISTORIQUE : Dans de nombreux pays, deux formulations de poudre sèche de formotérol pour inhalation sont disponibles pour un usage clinique ; l'une utilise un dispositif à dose unique (Foradil, Aerolizer) et l'autre, un dispositif à doses multiples (Oxis, Turbuhaler).

OBJECTIFS : Étudier l'effet bronchodilatateur du formotérol $12 \mu \mathrm{g} / \mathrm{dose}$ par inhalation au moyen de Aerolizer et de Turbuhaler, sur une période de $12 \mathrm{~h}$.

MODÈLE DE L'ÉTUDE : Étude croisée, randomisée, à double insu et contrôlée par placebo. Le volume expiratoire maximum/seconde (VEMS) a été monitoré pendant une période de $12 \mathrm{~h}$.

PATIENTS : Dix neuf patients asthmatiques non-fumeurs ont été inclus dans l'essai sur la base d'une réversibilité de leurs symptômes en réponse à l'inhalation de salbutamol (soit $200 \mathrm{ou}$ $400 \mu \mathrm{g}$ administrés de façon cumulative ; réversibilité minimale de $15 \%)$.

RÉSULTATS : On n'a observé aucune différence significative entre les deux dispositifs de poudre sèche en ce qui concerne le changement à partir de la valeur de référence du VEMS sur une période de $12 \mathrm{~h}$, l'aire sous la courbe du VEMS pendant $12 \mathrm{~h}$ ou la valeur maximale du VEMS. L'amélioration du VEMS après l'inhalation de formotérol $12 \mu \mathrm{g} /$ dose par rapport au placebo était nettement significative pour les deux dispositifs.

CONCLUSIONS : Le formotérol en poudre sèche démontre une efficacité équivalente qu'il soit administré par Aerolizer ou par Turbuhaler.

Correspondence: Dr Jan Lötvall, The Lung Pharmacology Group, Department of Respiratory Medicine and Allergology, Göteborg University, Sahlgrenska University Hospital, Bruna Stråket 11, S-413 45 Göteborg, Sweden. Telephone +011-46-31-342967, fax+011-46-413290, e-mail jan.lotvall@mailer.mednet.gu.se 
$\mathrm{F}$ ormoterol fumarate (Foradil, Novartis Pharmaceuticals, Canada Inc, Dorval, Quebec) is a potent and selective beta2-adrenergic receptor agonist that is highly effective in relaxing bronchial smooth muscle (1-9). Formoterol dry powder has a rapid onset of action, as well as a duration of action of at least $12 \mathrm{~h}$. In single-dose trials in adults, $12 \mu \mathrm{g}$ and $24 \mu \mathrm{g}$ of formoterol aerosol and dry powder provide a rapid onset of action, within 1 to 3 mins (4-8). Also, dose-response studies with formoterol aerosol and dry powder demonstrate that a substantial portion of the bronchodilating effect is maintained at $12 \mathrm{~h}$ after inhalation $(2,9)$. Improvements in lung function and control of asthma symptoms with formoterol inhalation are maintained during up to five years of treatment without evidence of a reduced bronchodilator response or worsening of asthma control (10-13).

All available powder inhalers are driven by the inspiratory flow achieved by the patient, and the dose deposited in the airways is dependent on several factors, including the inspiratory effort produced by the patient, the inbuilt resistance of the inhaler and the resulting inspiratory flow. Dry powder inhalers may have slightly different deposition characteristics, depending on the profile of aerosol delivered. Bronchodilators have traditionally been delivered via propellant driven pressurized metered dose inhaler (pMDI). However, total drug dose delivered with dry powder devices appears to be similar to that delivered with traditional pMDI (14-18).
Two dry powder formulations of inhaled formoterol have become available for clinical use. One uses a single-dose device (previously known as the Inhaled Single Formulation devise, Aerolizer, Novartis Pharma, Basel, Switzerland/Italseber Farmaceutici, Italy) and the other a multipledose device (Oxis/formoterol/Turbuhaler, Astra Draco, Lund, Sweden). Both these devices use lactose as a carrier substance, and both are breath actuated.

The aim of the present study was to compare the clinical efficacy of $12 \mu \mathrm{g}$ formoterol when delivered by either Aerolizer or Turbuhaler to adult patients with reversible airflow limitation.

\section{MATERIALS, PATIENTS AND METHODS}

The single-dose delivery device (Aerolizer) has a low internal resistance, and a gelatine capsule containing $12 \mu \mathrm{g}$ formoterol is loaded in the capsule chamber before use. When the patient inspires through the device, the capsule is lifted out of the capsule chamber into the inhalation chamber where it rotates to release powder (formoterol and lactose) into the airstream. The multiple-dose delivery device (Turbuhaler) has a higher internal resistance and contains 60 doses of either $6 \mu \mathrm{g}$ or $12 \mu \mathrm{g}$ formoterol. This device is activated by turning a knob at the bottom of the device, and one dose of 6 $\mu \mathrm{g}$ or $12 \mu \mathrm{g}$ is released when the patient inspires through the device. The turbulence in the mouthpiece generates the parti-

TABLE 1

Patient characteristics and lung function data (forced expiratory volume in $1 \mathrm{~s}$ [FEV 1 ) of 19 patients testing bronchodilation with formoterol delivered by Aerolizer or Turbuhaler

\begin{tabular}{|c|c|c|c|c|c|c|c|}
\hline Patient number & Sex & Age (years) & Height (cm) & Weight (kg) & $\mathrm{FEV}_{1}$ basal & Predicted FEV 1 & $\mathrm{FEV}_{1}(\%$ predicted $)$ \\
\hline 1 & Male & 67 & 176 & 90 & 1.81 & 3.16 & 57 \\
\hline 2 & Female & 72 & 162 & 66 & 1.28 & 2.02 & 63 \\
\hline 3 & Male & 65 & 183 & 83 & 2.29 & 3.52 & 65 \\
\hline 4 & Female & 52 & 166 & 66 & 1.90 & 2.68 & 71 \\
\hline 5 & Female & 68 & 168 & 119 & 1.38 & 2.31 & 60 \\
\hline 6 & Female & 50 & 168 & 72 & 1.27 & 2.81 & 45 \\
\hline 7 & Female & 50 & 165 & 92 & 1.81 & 2.69 & 67 \\
\hline 8 & Male & 72 & 171 & 88 & 1.34 & 2.80 & 48 \\
\hline 9 & Male & 60 & 163 & 67 & 2.62 & 2.81 & 93 \\
\hline 10 & Female & 51 & 175 & 88 & 2.29 & 3.06 & 75 \\
\hline $11^{*}$ & Male & 37 & 184 & 85 & 2.79 & 4.38 & 64 \\
\hline 12 & Male & 71 & 178 & 82 & 1.56 & 3.13 & 50 \\
\hline 13 & Male & 73 & 178 & 94 & 1.98 & 3.08 & 64 \\
\hline 19 & Female & 52 & 165 & 93 & 2.41 & 2.64 & 91 \\
\hline 20 & Male & 49 & 186 & 78 & 3.93 & 4.12 & 95 \\
\hline 21 & Female & 67 & 168 & 56 & 2.48 & 2.39 & 104 \\
\hline 22 & Male & 30 & 179 & 72 & 3.39 & 4.39 & 77 \\
\hline 23 & Male & 25 & 183 & 88 & 3.90 & 4.68 & 83 \\
\hline 24 & $F$ & 44 & 167 & 63 & 2.56 & 2.92 & 88 \\
\hline MEAN & & 55 & 173 & 81 & 2.26 & 3.13 & 72 \\
\hline SEM & & & & 3 & 0.18 & 0.17 & 4 \\
\hline
\end{tabular}

${ }^{*}$ The patient discontinued treatment after visit 3 


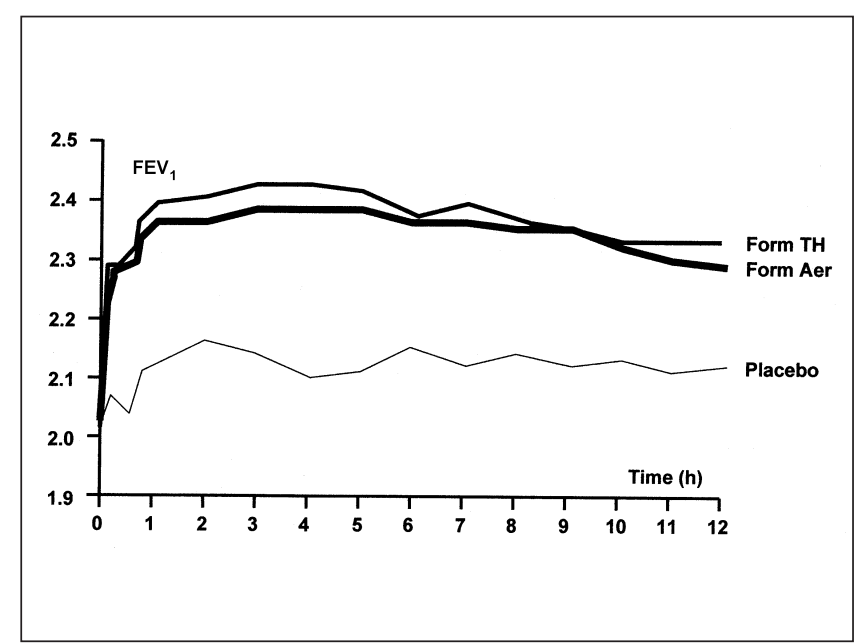

Figure 1) Time course of forced expiratory volume in $1 s\left(F E V_{1}\right)$ after single dose of formoterol $12 \mu \mathrm{g}$ given by Aerolizer (Aer) (Novartis Pharma, Basel, Switzerland) compared with formoterol $12 \mu \mathrm{g}$ by Turbuhaler (TH) (Astra Draco, Lund, Sweden) and placebo (including all evaluable patients, $n=18$ )

cles delivered to the patient. The dose delivered to the lungs and the distribution of the aerosol in the lung may thus differ between the two devices. Because formoterol is a potent beta2-adrenergic receptor agonist, even small differences may be clinically relevant to the patient in terms of efficacy and safety.

Patients: Nineteen nonsmoking patients (mean age 55 years, range 25 to 73 years; nine females, 10 males) with moderate asthma (defined according to the American Thoracic Society criteria) requiring daily treatment with inhaled bronchodilatators and corticosteroids were included in the trial. One patient attended only three of four visits. Patient data are presented in Table 1. In all, the diagnosis of chronic reversible obstructive airways disease (with forced expiratory volume in $1 \mathrm{~s}\left[\mathrm{FEV}_{1}\right]$ more than $40 \%$ of predicted) had been previously established. After written consent was obtained, lung function $\left(\mathrm{FEV}_{1}\right)$ was measured. Mean $\mathrm{FEV}_{1}$ at inclusion was $2.26 \mathrm{~L}$, and mean $\mathrm{FEV}_{1}$ per cent predicted was $72 \%$. A reversibilty of at least $15 \%$ of $\mathrm{FEV}_{1}$ had to be documented 15 mins after $200 \mu \mathrm{g}$ or $400 \mu \mathrm{g}$ salbutamol powder was delivered by Diskhaler (Glaxo Wellcome Ltd, Ware, United Kingdom). The reason for this reversibility test was to ensure response to a bronchodilating drug in the participating patients. Eight of the patients used salbutamol as concomitant medication, six generic salbutamol, five terbutaline and four salmeterol (Serevent, Glaxo Wellcome Inc, Mississauga, Ontario). Only one used ipratropium bromide (Atrovent, Boehringher Ingelheim Ltd, Laval, Quebec), one formoterol (Oxis Turbuhaler) and one Theo-dur (Astra Draco, Lund, Sweden). All patients were on inhaled glucocorticoids.

The study was approved by the Ethics Committee at Göteborg University, Gothenburg, Sweden, and was performed in accordance with the Declaration of Helsinki and conducted according to the guidelines for Good Clinical Practice.

Study design: Patients were randomly assigned to one of the sequences of the three trial treatments by a computer generated list at visit 2 . The order of inhalation from either device on each study day was randomized among patients. All treatments were administered between 07:00 and 10:00 on visits 2, 3 and 4, and were supervised by a technician or nurse. Between the treatment visits, a washout period of at least three days ( $72 \mathrm{~h}$ ), and up to 10 days, was scheduled. Patients continued to use their usual asthma medication during the study.

Methods: $\mathrm{FEV}_{1}$ was measured by dry spirometer (Vitalograph Ltd, Buckingham, United Kingdom). Just before the administration of formoterol or placebo via Aerolizer or Turbuhaler devices, at 3, 7, 15, 30 and 45 mins, and 1, 2, 3, 4, 5, $6,7,8,9,10,11$ and $12 \mathrm{~h}$ after medication the best of three forced expirations were accepted and registered in the case report form. Only one measurement was performed at 3, 7, 15 and 30 mins to save time.

Data analysis: The primary objective of this study was to compare the efficacy of a single dose of $12 \mu \mathrm{g}$ formoterol via the Aerolizer device and the Turbuhaler device versus placebo. The primary variable for this comparison was the $12 \mathrm{~h}$ average $\mathrm{FEV}_{1}$ (area under the $\mathrm{FEV}_{1}$ curve versus time, divided by $12 \mathrm{~h}$ ). Secondary objectives of the study were to compare the maximum value of $\mathrm{FEV}_{1}$ (irrespective of time point that this is achieved), $\mathrm{FEV}_{1}$ at all time points, and percentage change from predose baseline at all time points. $\mathrm{Pa}-$ tients who received treatment and had efficacy measurements for at least two treatment days were analyzed. For the primary variables, confirmatory analyses were performed at a significance level of 5\% (two-sided). No adjustment for multiple testing was performed. The treatment contrasts were tested in the following order: formoterol Aerolizer versus placebo, formoterol Turbuhaler versus placebo, and formoterol Aerolizer versus formoterol Turbuhaler. All FEV 1 data were log-transformed before statistical analysis.

ANCOVA, including log-transformed baseline $\mathrm{FEV}_{1}$ as a covariate, was performed to test for differences among treatments. The results (eg, confidence interval) were antilogged to be expressed as ratios.

\section{RESULTS}

There were no differences in baseline $\mathrm{FEV}_{1}$ among the different study days. The time-course of $\mathrm{FEV}_{1}$ over $12 \mathrm{~h}$ on the different study days is shown in Figure 1. The time course of the mean change in $\mathrm{FEV}_{1}$ following the single dose of formoterol $12 \mu \mathrm{g}$ by both the Aerolizer and Turbuhaler was significantly greater than placebo at each time point. The differences between Aerolizer and Turbuhaler were not significant at any time point.

The maximal $\mathrm{FEV}_{1}$ was $2.27 \pm 0.03 \mathrm{~L}$ on the placebo day, and $2.47 \pm 0.035 \mathrm{~L}$ and $2.51 \pm 0.04 \mathrm{~L}$ on the Aerolizer and Turbuhaler days, respectively $(\mathrm{P}<0.01$ for both Aerolizer and Turbuhaler versus placebo, P not significant between Aerolizer and Turbuhaler).

The mean of $\mathrm{FEV}_{1}$ over $12 \mathrm{~h}$, which is considered to be the primary statistical variable in this study, was $2.12 \pm 0.03 \mathrm{~L}$ on the placebo day, and $2.36 \pm 0.035$ and $2.38 \pm 0.035 \mathrm{~L}$ on the 
Aerolizer and Turbuhaler days, respectively $(\mathrm{P}<0.01$ for both Aerolizer and Turbuhaler versus placebo; $\mathrm{P}$ not significant between Aerolizer and Turbuhaler). No statistical difference was detected between the single dose of formoterol $12 \mu \mathrm{g}$ by the Aerolizer and Turbuhaler, using the primary variable (Aerolizer $1 \%$ lower; $\mathrm{CI}-3 \%$ to $1 \%$; $\mathrm{P}=0.36$ ). However, the differences between formoterol $12 \mu \mathrm{g}$ Aerolizer and placebo (11\%; CI 9\% to 13\%; $\mathrm{P}=0.0001$ ) and between formoterol $12 \mu \mathrm{g}$ Turbuhaler and placebo (12\%; CI $10 \%$ to $14 \%$; $\mathrm{P}=0.0001$ ) were highly significant.

No patient reported any serious adverse reactions during the trial, and there were no trends in the differences in adverse reactions between formoterol given by either device.

\section{DISCUSSION}

The present placebo controlled, double-blind and double dummy, single-dose cross-over study was performed to compare the bronchodilator effect of formoterol $12 \mu \mathrm{g}$ when delivered by the two different dry powder inhalers, the Aerolizer and Turbuhaler. Formoterol $12 \mu \mathrm{g}$ given by either device produced highly significant bronchodilation versus placebo. However, the Aerolizer and Turbuhaler caused very similar bronchodilation during the $12 \mathrm{~h}$ after administration, with a very similar onset of action and duration of effect; both treatments were well tolerated. Thus, no difference in efficacy of formoterol $12 \mu \mathrm{g}$ given via Aerolizer or Turbuhaler was detected. More important, some inhalation devices have been suggested to cause better lung deposition than others, which, under some conditions, may lead to improved local efficacy of the inhaled drug (19). Thus, from a clinical point of view, it is important to establish whether formoterol is more efficacious when given by either device compared in the present study.

Dry powder inhalers (such as the Aerolizer and the Turbuhaler) are increasingly being used instead of conventional MDIs, mainly because they do not contain chlorofluorocarbon propellants and lubricants or surfactants (19). Furthermore, the dry powder inhalers do not require synchronized inhalation with actuation of the device, which is required with pMDIs. This may further add to their success.

We chose to compare single and equivalent label doses of

\section{REFERENCES}

1. Löfdahl CG, Swedmyr N. Formoterol fumarate, a new $\beta 2$-adrenoceptor agonist. Acute studies of selectivity and duration of effect after inhaled and oral administration. Allergy 1989;44:264-71.

2. Wegener T, Hedenström H, Melender B. Rapid onset of action of inhaled formoterol in asthmatic patients. Chest 1992;102:535-8.

3. Arvidsson P, Larsson S, Löfdahl CG, Melander B, Wåhlander L, Swedmyr N. Inhaled formoterol during one year in asthma: a comparison with salbutamol. Eur Respir J 1991;4:1168-73.

4. Barnes PJ. New drugs for asthma. Clin Exp Allergy 1996;26:738-45.

5. Nielsen KG, Skov M, Klug B, Ifversen M, Bisgaard H. Flow-dependent effect of formoterol dry-powder inhaled from the Aerolizer. Eur Respir J 1997;10:2105-9.

6. Palmqvist M, Persson G, Lazer L, Rosenborg J, Larsson P, Lötvall J Inhaled dry-powder formoterol and salmeterol in asthmatic patients: onset of action, duration of effect and potency. Eur Respir J 1997; 10:2484-9.

7. Derom E, Pauwels RA. Time-course of bronchodilating effect of formoterol given by either device of several reasons. First, these doses are the most commonly given by either device in the clinical situation. Furthermore, $12 \mu \mathrm{g}$ is the most commonly studied dose by either device, and causes clinically clear, although not always maximal, effects (1-3,5-9). We also chose to evaluate one single dose of the drug because the effects of multiple dosing can lead to accumulation of effect $(10,11,20)$, with an increased concentration of drug within the airway wall; this situaton could influence the results. Multiple dosing studies also substantially increase the variability of the results due to a prolonged observation time and increased variability of the disease, which means that many more patients need to be evaluated in such comparisons as calculated by power calculations (19). Also, we cannot exclude the possibility that the bronchodilating effects observed are not on the plateau of the dose-response curve in the patients studied.

Our study included an sufficiently high number of patients to compare the bronchodilating effect of the single dose of formoterol by either device (1-9). The small numeric difference in maximal $\mathrm{FEV}_{1}$ between the two devices, in favour of the Turbuhaler, was not statistically significant, and, in view of the small observed difference in $\mathrm{FEV}_{1}$, is unlikely to be clinically important. This study compared the devices in a laboratory setting, and their effectiveness in a large clinical patient population has yet to be studied.

\section{CONCLUSIONS}

Formoterol $12 \mu \mathrm{g}$ is similarly effective as a bronchodilator when given as dry powder by either Aerolizer or Turbuhaler at a single dose; thus, there is no major clinical difference in the efficacy of inhaled formoterol when given by these devices.

ACKNOWLEDGEMENTS: We are grateful to Ms Helén Törnqvist, Eva Carlgren and Marianne Robertsson for their excellent technical assistance, as well as Ms Jeanette Fant, Mr Bo Mellander, Dr Giuseppe di Benedetto and Dr Thomas Ibsen for their helpful discussion. We are also grateful to Mr Lars Wåhlader and Mr G Rapatz for statistical analysis. The study was financed by Novartis Pharma, Basel, Switzerland. inhaled formoterol, a potent and long acting sympathomimetic. Thorax 1992;47:30-3.

8. Wallin A, Sandström T, Rosenhall L, Melander B. Time course and duration of bronchodilatation with formoterol dry powder in patients with stable asthma. Thorax 1993;48:611-4.

9. Maesen FPV, Smeets JJ, Gubbelmans HLL, Zweers P. Bronchodilator effect of inhaled formoterol vs salbutamol over 12 hours. Chest 1990;97:590-4.

10. Schreurs AJM, Sinninghe Damsté HEJ, de Graaff CS, Greefhorst APM. A dose-response study with formoterol Turbuhaler as maintenance therapy in asthmatic patients. Eur Respir J 1996;9:1678-83.

11. Kesten S, Chapman KR, Broder I, et al. A three-month comparison of twice daily inhaled formoterol versus four times daily inhaled albuterol in the management of stable asthma. Am Rev Respir Dis 1991;144:622-5.

12. Faulds D, Hollingshead LM, Goa KL. Formoterol. A review of its 


\section{Lötvall et al}

pharmacological properties and therapeutic potential in reversible obstructive airways disease. Drugs 1991;42:115-37.

13. Bartow RA, Brogden RN. Formoterol. An update of its pharmacological properties and therapeutic efficacy in the management of asthma. Drugs 1998;55:303-22.

14. Rabe FK, Jörres R, Nowak D, Behr N, Magnussen H. Comparison of the effects of salmeterol and formoterol on airway tone and responsiveness over 24 hours in bronchial asthma. Am Rev Respir Dis 1993; 147:1436-41.

15. Moore RH, Khan A, Dickey BF. Long-acting inhaled beta2-agonists in asthma therapy. Chest 1998;113:1095-108.

16. Selroos O. The pharmacological and clinical properties of Oxis (formoterol) Turbuhaler. Allergy 1998;53(42 Suppl):14-9.

17. Thomson NC, Angus R, Quebe-Fehling E, Brambilla R. Efficacy and tolerability of formoterol in elderly patients with reversible obstructive airways disease. Respir Med 1998;92:562-7.

18. Selroos O, Pietinalho A, Riska H. Delivery devices for inhaled asthma medication. Clinical implications of differences of effectiveness. Clin Immunother 1996;6:273-99.

19. Brown PH, Ning ACWS, Greening AP, McLean A, Crompton GK. Peak inspiratory flow through Turbuhaler in acute asthma. Eur Respir J 1995;8:1940-1.

20. Steffensen I, Faurschou P, Riska H, Rostrup J, Wegener T. Inhaled formoterol dry powder in the treatment of patients with reversible obstructive airways disease. A 3-month, placebo-controlled comparison of the efficacy and safety of formoterol and salbutamol, followed by a 12 -month trial with formoterol. Allergy 1995;50:657-63. 


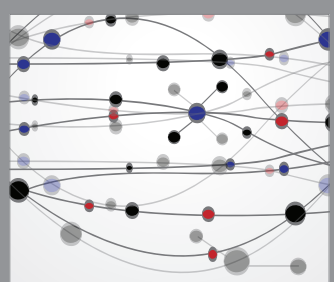

The Scientific World Journal
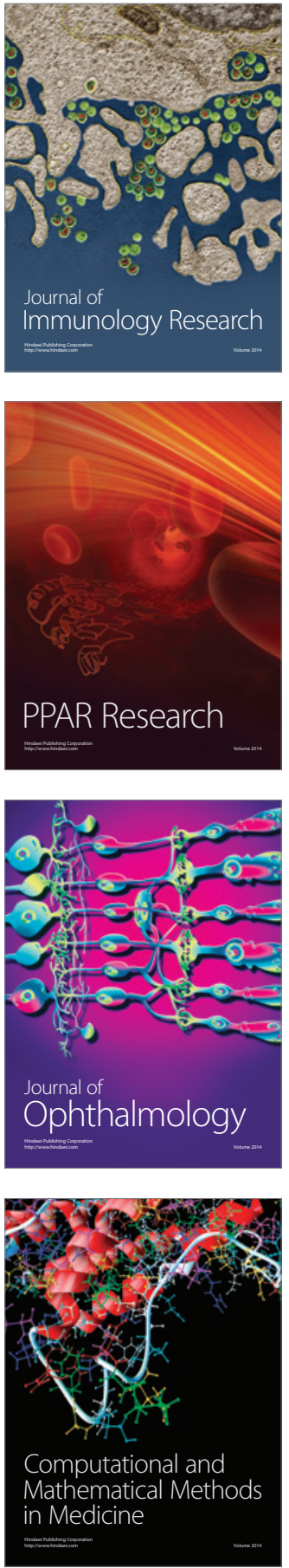

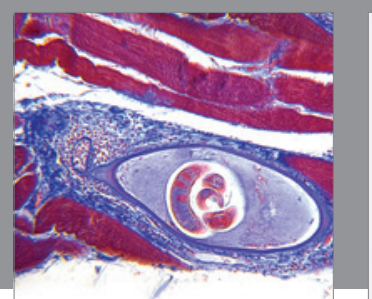

Gastroenterology Research and Practice

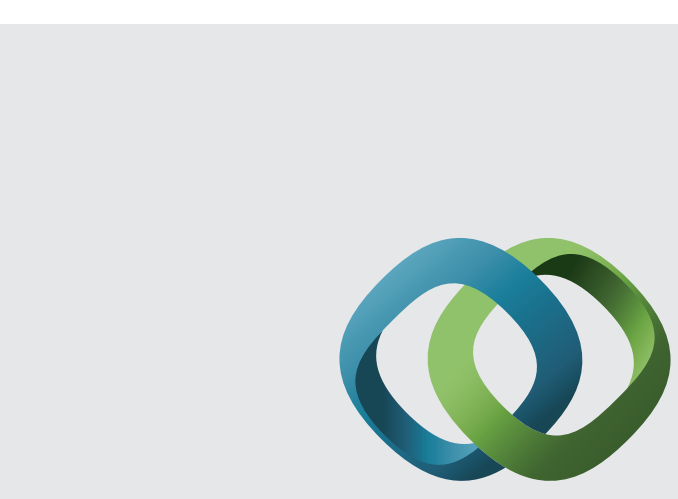

\section{Hindawi}

Submit your manuscripts at

http://www.hindawi.com
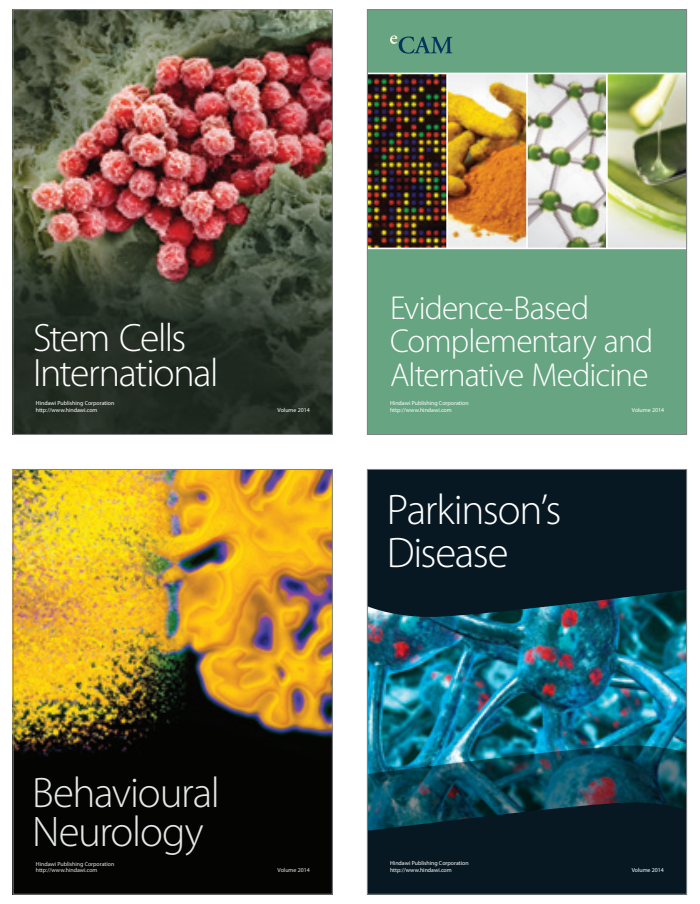
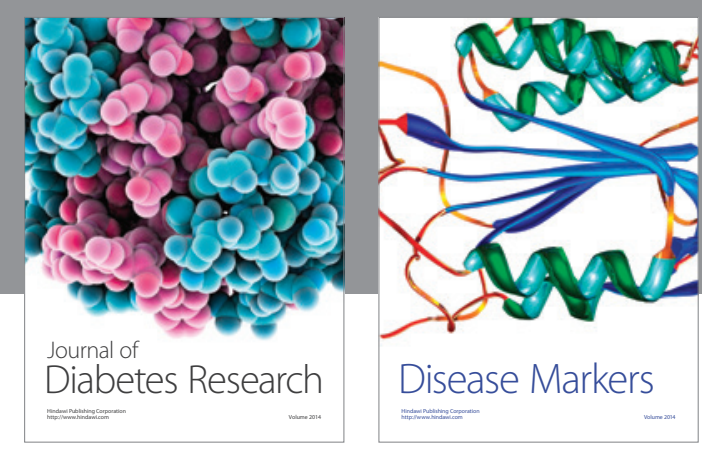

Disease Markers
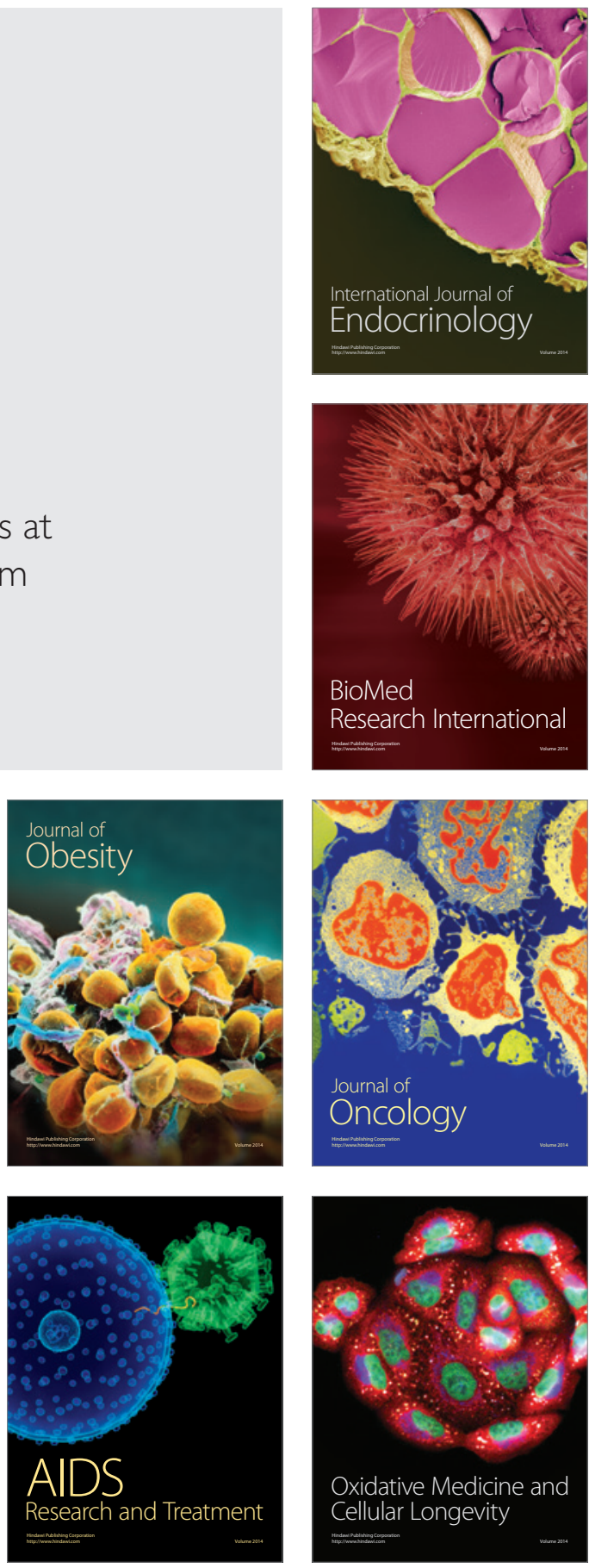